Newfoundland and Labrador Studies

\title{
Joel Thomas Hynes. We'll All Be Burnt in Our Beds Some Night. Toronto: Harper Collins, 2017. ISBN 978-1-44344-783-6
}

\section{Melanie Hurley}

Volume 33, numéro 1, 2018

URI : https://id.erudit.org/iderudit/1055875ar

DOI : https://doi.org/10.7202/1055875ar

Aller au sommaire du numéro

\section{Éditeur(s)}

Faculty of Arts, Memorial University

\section{ISSN}

1719-1726 (imprimé)

1715-1430 (numérique)

Découvrir la revue

Citer ce compte rendu

Hurley, M. (2018). Compte rendu de [Joel Thomas Hynes. We'll All Be Burnt in Our Beds Some Night. Toronto: Harper Collins, 2017. ISBN 978-1-44344-783-6]. Newfoundland and Labrador Studies, 33(1). https://doi.org/10.7202/1055875ar d'utilisation que vous pouvez consulter en ligne. 
Joel Thomas Hynes. We'll All Be Burnt in Our Beds Some Night. Toronto: Harper Collins, 2017. ISBN 978-1-44344-783-6

Just before I began reading Joel Thomas Hynes's We'll All Be Burned in Our Beds Some Night, it won the prestigious Governor General's Award for English-language fiction, an event that changed the context of my reading, and along with it, my perceptions of the book, making reviewing it much more challenging than if I had come to the book blind. I felt more pressure not only to think that the book was original and well-crafted, but also to enjoy reading it in the same way I feel obliged to find quality in and to like award-winning films or "classic" texts. At the same time, people who knew I was reading the book began offering me their opinions on Hynes's work and persona, further complicating my reading context. In the end, I find I cannot separate how I interpret the novel from the experience of reading it; thus, the review must incorporate both.

The novel explores the dark side of Newfoundland: Hynes weaves together familiar names, places, and stories to create a gritty, startling tale that, for better or worse, is likely to resonate with readers from Newfoundland or who have lived in the province long term. Its world is shockingly lacking in empathy, and through protagonist Johnny Keough's experiences it probes into how this absence perpetuates itself. Initially, Johnny is not a particularly likeable character, which caused me to have difficulty engaging with the text, and his story is rife with domestic violence and other forms of abuse (sexual, child, and animal), depictions that I found disturbing (an assessment with which I am sure many other readers would agree). Yet, through the adept use of both the limited third-person and the first-person points of view to delve into these unpleasant realities, Hynes manages to craft a moving, emotionally charged read that I eventually found quite compelling. If you are like me, Hynes's writing will make you feel, by turns, annoyed, disgusted, and heartbroken, and it will probably have you cheering for Johnny, despite yourself, by the time the novel finishes. 
Hynes makes heavy use of familiar places, names, and news stories to lend his narrative a high degree of verisimilitude, and his focus on local culture makes his work like that of many other Newfoundland writers. The novel opens in St. John's, and it frequently references wellknown places there, such as the Atlantic Place steps (52), the Peter Easton pub (72), and Fred's Records (121), details that made me feel like I was reading about the lived experiences that go on around me each day. Certain featured names are characteristic of Newfoundland: "Keough" is a surname associated with the Southern Shore (the location of many of Johnny's memories), while names ending in "ie" or "y" (e.g., Johnny, Mikey, and Stevie) are prevalent in the province. At times, the novel alludes to real news stories, such as when, awaiting trial for allegedly assaulting his girlfriend Madonna with a teapot, Johnny notices "that evil cunt from CBS who burnt his house down with his five-year-old daughter inside" (58), a moment that evokes Quinn Butt's alleged murder. Hynes's attention to local detail is not at all unusual for Newfoundland writers. From Wayne Johnston's The Colony of Unrequited Dreams (1998) to Ron Pumphrey's autobiographical Human Beans (2007), books by Newfoundland writers tend to be explicitly about life in this province, albeit in different historical periods. Hynes's novel adds to this body of literature, and his contribution focuses on contemporary life and the world of recent memory, making it likely to appeal to a younger generation of readers. The connections to the local at the level of quotidian details and at the level of the Newfoundland literary corpus breathe life into Hynes's characters, and it makes the novel's world hauntingly, and perhaps distressingly, familiar to long-time residents of the province.

The aspect of Johnny Keough's world that is particularly distressing is the lack of empathy that its characters exhibit, and Hynes cleverly integrates definitions of sociopathy and empathy into the narrative to highlight the apathetic nature of its characters and to place this opposition at the heart of the novel. McGregor, a prison guard at the Whitbourne Youth Correctional Facility, labels Johnny a sociopath, a term that the latter must research. Johnny discovers that it is someone 
who cannot "form human attachment" and who exhibits "an abnormal lack of empathy," and he must then look up empathy, which he learns is "the capacity to recognize, and, to some extent, share feelings with others in society" (142). He recognizes that he does not have this ability and identifies with the sociopath label; to him, empathy is just "a bullshit word" (117). However, this inability to empathize extends far beyond Johnny, as the people around him do horrible things to him and to others, and they never appear to regret any of it. Pius, Johnny's adoptive father/biological grandfather regularly and unrepentantly beat both Johnny and Tanya (Johnny's biological mother) for years, while Pius's wife, who only ever receives the moniker "Old Bat Shit," finds herself capable of ignoring a child with a severely cut finger (112-13). Even minor characters act cruelly, such as Leo Davis, who verbally and physically assaults his girlfriend (61). Empathy versus sociopathy is the key opposition in this novel, and Hynes's inclusion of their definitions sharpens the reader's attention to this point, bringing into focus the terrible harshness and coldness of this world.

A significant amount of abuse stems from the characters' impassiveness, and it is this aspect of the novel that some readers, such as myself, may find hard to stomach; however, this unpleasant feature of the novel extends a lack of empathy into the relationship between the reader and the protagonist, as Johnny's treatment of others makes it hard to care about him. The treatment of women in the novel is disturbing, although it does complement current events, such as the \#MeToo campaign. Men attack women frequently in this world, as Madonna and the teapot (14-17), Tanya's rape (190-91), Johnny's assault on Lizzy O'Neill in a twine shed (208-13), and the bruises on Leo Davis's girlfriend (61) all evidence. The teapot incident makes it rather difficult to like Johnny, since his story that he held the teapot up in self-defence and Madonna ran into it $(14,28)$ is, frankly, ridiculous, and it is hard to feel for a domestic abuser; at least, it is hard for me. Furthering my dislike of Johnny were the hints dropped about the incident with his neighbour's hens $(34,186,225)$, which cause the reader (rightfully) to suspect him of cruelty to animals, a form of abuse 
that viscerally upsets me. Although Johnny's use of his dog Scrapper to kill Mikey's hens (225-28) was not as gruesome as I had imagined, it was still disconcerting. Scrapper's subsequent death by shooting (228), a short reference, was even worse for me, as I adore dogs, but it is also an event that effectively continues the cycle of violence and apathy. Readers who become queasy at descriptions of rape, physical abuse, and/or animal abuse, or who want a protagonist with whom they can easily empathize, may find this book to be a tough read. Nonetheless, I recognize that my own lack of empathy for Johnny mirrored his psychological state, and thus the book throws the reader into the novel's reality, increasing the impact of its (un)emotional world.

It is Hynes's supremely intelligent use of point of view that may change the reader's mind about Johnny, as the shifts between the limited third-person and the first-person elaborate upon the opposition between empathy and sociopathy, provocatively illustrating how this harsh world forces individuals to become emotionally detached, and it draws the reader into Johnny's struggle to become a subject with a full emotional life. Johnny is the narrator of the entire novel, but he usually refers to himself in the third person, obfuscating this point and positioning himself as the object of his own observation. Johnny developed his penchant for impassivity and self-observation at a young age as a response to the maltreatment he endured. He remembers Pius beating him with "a busted work boot" as punishment for having stolen "a load of grub" from the cabin of the Ledwells' longliner, and he recalls the sensation of "watchin it all from somewhere up above, observing the onslaught from up in the farthest corner of the room" (181). Pius is literally beating his adopted son's ability to experience normal emotions out of him. Pius's actions reproduce his own coldness and violent tendencies in Johnny, as seen when Johnny punches Pius twice in the face (140-41) and when he assaults Madonna (14-17). However, Johnny does reclaim his ability to empathize, which the novel indicates through the increased use of the first-person point of view as it progresses. The first-person initially appears in flashback sequences, and then infiltrates the narrative present, becoming the dominant 
point of view in the last two chapters. As the first-person replaces the limited third-person, it also becomes easier for the reader to connect with Johnny, introducing empathy into all the places it was previously non-existent. Unfortunately, Johnny's death quickly snuffs out his emotional subjectivity (246). The novel may end in a beautiful afterlife (246-47), but the world of the here-and-now remains ruthless and bleak, keeping its harshness intact.

In my final assessment, I find that We'll All Be Burnt in Our Beds Some Night is thought-provoking, stirring, and, in places, heart-rending, but also shocking and disturbing. I believe that it is worthy of the Governor General's Award, but I also think it is a controversial text, and that readers will likely read it within the context of contentious issues in their everyday worlds. In this review, I have had to express my experience of the novel, which evolves out of my peculiar reading context and does not necessarily reflect the broader trends in audience responses. Nonetheless, I would suggest that, even if you hate it when you start, Johnny and his world have the power to imprint themselves on your mind, insinuate themselves into your emotions, and then stay with you long after you finish the book.

Melanie Hurley

Memorial University of Newfoundland

Jennifer Bowering Delisle. The Bosun Chair. Edmonton: NeWest Press, 2017. ISBN 978-1-92645-587-7

It is dangerous to allow an author too much authority to frame her work just the way she wants, but The Bosun Chair is best understood, and most kindly reviewed, in the context of the author's own interpretation of her work as the subgenre "second-generation diaspora literature." Delisle tells us in her prologue of the rootlessness of hearing stories of "home," a home that is not her natal Alberta but her parents' 